\title{
Kaji Terap Kecerdasan Buatan di Badan Pengkajian dan Penerapan Teknologi
}

\author{
Hammam Riza \\ Badan Pengkajian dan \\ Penerapan Teknologi \\ Gedung B.J Habibie, Lantai 2 \\ Jl. M.H Thamrin No 8 \\ Jakarta Pusat DKI Jakarta \\ 10340 \\ hammam.riza@bppt.go.id
}

\author{
Anto Satriyo Nugroho \\ Pusat Teknologi Informasi dan \\ Komunikasi \\ Badan Pengkajian dan \\ Penerapan Teknologi \\ Gedung Teknologi 3, Lantai 3 \\ Puspiptek \\ Tanggerang Selatan 15314 \\ anto.satriyo@bppt.go.id
}

\author{
Gunarso \\ Pusat Teknologi Informasi dan \\ Komunikasi \\ Badan Pengkajian dan \\ Penerapan Teknologi \\ Gedung Teknologi 3, Lantai 3 \\ Puspiptek \\ Tanggerang Selatan 15314 \\ gunarso@bppt.go.id
}

\begin{abstract}
Abstrak-BPPT mulai melakukan penelitian dan pengembangan di bidang kecerdasan buatan sejak tahun 1987 yaitu dengan keterlibatannya dalam proyek sistem mesin penerjemah multi bahasa yang disponsori oleh pemerintah Jepang. Penelitian di bidang mesin penerjemah ini terus berlanjut seiring dengan keterlibatan BPPT dalam beberapa proyek sesudahnya, antara lain proyek UNL, PAN Localization, ASEAN-MT, dan USTAR. Beberapa metode pun telah digunakan dalam pembuatan sistem mesin penerjemah, dari penggunaan metode Interlingua yang berbasis aturan, berbasis statistik, sampai dengan metode sequence-to-sequence yang menggunakan deep learning. Di bidang pemrosesan bahasa alami lainnya, BPPT juga melakukan riset dalam bidang pengenalan wicara atau ASR (Automatic Speech Recognition) yang telah menghasilkan produk komersial Perisalah yang berfungsi untuk mencatat segala bentuk pembicaraan di dalam rapat dan membuat notulensi secara cepat. Di bidang pembangkit wicara atau TTS (Text-to-Speech) BPPT telah memulai risetnya sejak tahun 2001 yang saat itu masih menggunakan metode diphone concatenation hingga saat ini menggunakan metode endto-end. Selain riset di bidang teknologi pemrosesan alami, BPPT juga melakukan penelitian aplikasi kecerdasan buatan dalam pengolahan citra. Antara lain pengembangan sistem diagnosis Malaria, identifikasi individu memakai sidik jari, selaput pelangi, maupun wajah. Penelitian di bidang biometrik ini seiring dengan tugas BPPT melakukan pendampingan Kementrian Dalam Negeri dalam implementasi KTP elektronik. Selain itu BPPT juga melakukan layanan pengujian KTP-elektronik bagi industri dalam negeri dari sisi teknologi kartu cerdas dan teknologi biometrik. BPPT juga turut mempersiapkan perancangan standar nasional biometrik (SNI) untuk pertukaran data, misalnya format penyimpanan data sidik jari pada chip KTP elektronik. Pada tahun 2019 BPPT memiliki Pusat Unggulan Iptek Biometrik yang menggalang kegiatan litbangyasa maupun layanan teknologi di bidang biometrik untuk kemandirian bangsa.
\end{abstract}

Keywords - kecerdasan buatan, mesin penerjemah, mesin penerjemah multi bahasa, Interlingua, metode end-to-end, pengenalan wicara, Automatic Speech Recognition, Perisalah, pembangkit wicara, Text-to-Speech, diphone concatenation, metode end-toend, biometrik, KTP elektronik, Malaria

\section{Pendahuluan}


Perhatian di bidang kecerdasan dewasa ini meningkat. Terlihat dari ragamnya penelitian yang dilakukan perguruan tinggi, lembaga litbang, maupun industri yang mendiseminasikan penelitiannya dengan produk-produk kecerdasan buatan. Badan Pengkajian dan Penerapan Teknologi (BPPT) turut aktif dalam melakukan penelitian kecerdasan buatan dan memberikan layanan bagi masyarakat. Diawali dari keterlibatan BPPT dalam proyek sistem mesin penerjemah tahun 1987, yaitu dengan keterlibatannya dalam proyek sistem mesin penerjemah multi bahasa yang disponsori oleh pemerintah Jepang. Penelitian di bidang mesin penerjemah ini terus berlanjut seiring dengan keterlibatan BPPT dalam beberapa proyek sesudahnya, antara lain proyek Universal Networking Language (UNL), PAN Localization, ASEAN-MT, U-STAR. Salah satu produk yang dikomersialkan adalah "Perisalah", yang berfungsi untuk mencatat segala bentuk pembicaraan di dalam rapat dan membuat notulensi secara cepat. Riset di bidang teknologi pemrosesan bahasa alami, berlanjut ke arah Speech-to-Speech, yang mengintegrasikan teknologi pengenalan wicara, machine translation dan pembangkit wicara (Text-to-Speech Synthesizer).

Selain riset di bidang teknologi pemrosesan alami, BPPT juga melakukan penelitian aplikasi kecerdasan buatan dalam pengolahan citra. Antara lain pengembangan sistem diagnosis Malaria, bekerja sama dengan peneliti di lembaga Eijkman dan perguruan tinggi. Selain itu penelitian juga dilakukan untuk identifikasi individu memakai sidik jari, selaput pelangi, maupun wajah (multimodal biometrik). Penelitian di bidang biometrik ini seiring dengan tugas BPPT melakukan pendampingan Kementrian Dalam Negeri dalam implementasi KTP elektronik di Indonesia. Selain kegiatan litbangyasa, BPPT juga memberikan layanan pengujian KTP-elektronik bagi industri dalam negeri yang akan memproduksi perangkat pembaca KTP-elektronik. Selain itu untuk turut mempersiapkan perancangan standar nasional biometrik untuk pertukaran data, misalnya format penyimpanan data sidik jari pada chip KTP elektronik.

Bab II makalah ini membahas resume kegiatan litbangyasa yang dilakukan. Antara lain mesin penerjemah, pengenalan wicara, pembangkit wicara, sistem penerjemah wicara-ke-wicara mobile berbasis Android, pengembangan alat diagnosis Malaria dari apusan darah, pengembangan sistem identifikasi berbasis multimodal biometrik, pembuatan standar pertukaran data Biometrik, Pusat Unggulan Iptek (PUI) Biometrik dan layanan teknologi bagi industri pengembang perangkat pembaca KTP elektronik. Bab III menutup paparan makalah ini, menyimpulkan arah ke depan kegiatan litbangyasa yang dilakukan BPPT.

\section{Kegiatan KaJI TeraP Di BPPT}

\section{A. Mesin Penerjemah}

Sejarah riset BPPT di dalam bidang kecerdasan buatan, terutama pemrosesan bahasa alami telah dimulai sejak tahun 1987 yaitu sejak keterlibatan BPPT dalam proyek sistem penerjemah multi bahasa, dan diikuti oleh proyek-proyek lainnya seperti UNL (Universal Networking Language), ASEAN MT, PAN Localization, U-STAR (Universal Speech Translation Advance Research Consortium), Asian Language TreeBank (ALT), dll. Berikut beberapa proyek yang melibatkan BPPT dalam riset dan pengembangannya: 
1. Sistem Mesin Penerjemah Multi Bahasa

Cikal bakal riset kecerdasan buatan BPPT dimulai sejak tahun 1987, seiring dengan keterlibatannya dalam proyek kerjasama riset untuk mengembangkan sistem mesin penerjemah multi bahasa. Proyek dengan tajuk "The Research and Development Cooperation Project on a Machine Translation System for Japan and its Neighboring Countries" ini disponsori oleh pemerintah Jepang dan melibatkan lima negara yaitu China, Indonesia, Jepang, Malaysia, dan Thailand. Subjek penerjemahan adalah bahasa dari kelima negara yang terlibat yaitu Bahasa China, Bahasa Indonesia, Bahasa Jepang, Bahasa Malaysia, dan Bahasa Thailand. Lebih lanjut, metode Interlingua Machine Translation yang cocok untuk mesin penerjemah multi bahasa, telah diadopsi untuk pengembangan sistem mesin penerjemah di proyek ini.

BPPT yang mewakili Indonesia di dalam proyek ini berkewajiban untuk mengembangkan beberapa modul yang berkaitan dengan Bahasa Indonesia yaitu :

a. Kamus Elektronik Bahasa Indonesia yang memuat informasi gramatikal seperti informasi morfologi, informasi sintaksis, dan informasi semantik. Kamus juga memuat informasi korespondensi lema kamus dengan lema kamus dari bahasa lainnya serta Interlingua. Informasi-informasi ini digunakan oleh sistem analisis Bahasa Indonesia dan sistem Generasi (pembangkitan) Bahasa Indonesia.

b. Sistem Analisis Bahasa Indonesia yang berfungsi untuk mengubah kalimat bahasa Indonesia ke dalam representasi Interlingua.

c. Sistem Generasi Bahasa Indonesia yang berfungsi untuk mengubah representasi Interlingua ke dalam kalimat bahasa Indonesia.

d. Sistem Input/Output yang berfungsi untuk mengatur bagaimana kalimat dimasukkan ke dalam sistem dan bagaimana hasilnya ditampilkan.

e. Sistem Integrasi yang menggabungkan semua modul di atas ke dalam aplikasi tunggal Sistem Penerjemah Multi Bahasa.

Metode Interlingua adalah metode yang berbasis aturan (knowledgebased) sehingga sistem analisa dan sistem generasi yang dikembangkan mengikuti aturan gramatika (sintaksis) bahasa dari bahasa terkait. Untuk itu maka aturan-aturan dalam Sistem Analisa Bahasa Indonesia dibuat berdasarkan tata bahasa baku Bahasa Indonesia, dan demikian juga dengan sistem Generasi Bahasa Indonesia.

Proyek dibagi ke dalam tiga fase utama yaitu fase pertama meneliti elemen dasar sistem (1987 hingga 1988), fase kedua menangani pengembangan sistem (1989 hingga 1992), dan fase ketiga untuk perbaikan dan pembuktian sistem (1993 hingga 1994). Proyek ini berakhir pada bulan Maret 1995 dan dilanjutkan dengan kegiatan tindak lanjut (yang berakhir pada Maret 1997) untuk melihat kemajuan setiap negara 
yang pernah terlibat di dalam proyek ini dalam bidang pemrosesan bahasa alami pada umumnya dan mesin penerjemah secara khusus.

Sumber daya kebahasaan dan pengalaman yang dihasilkan dari proyek ini sangat berarti bagi BPPT dan menjadi modal utama dalam menangani beberapa proyek sesudahnya. Beberapa sumber daya yang dihasilkan dari proyek ini di antaranya adalah Kamus Elektronik Bahasa Indonesia, Aturan Produksi (production rule) Tata Bahasa dari Bahasa Indonesia, Korpus Teks Bahasa Indonesia, Gazetteer atau data nama terkait geografis Indonesia, dll.

\section{Universal Networking Languange}

Proyek UNL (Universal Networking Language) diinisiasi oleh UNUIAS (The United Nations University Institute for the Advanced Study) yang berkedudukan di Tokyo, pada tahun 1996. Pada awalnya, proyek ini diikuti oleh beberapa institusi yang mewakilil enam bahasa resmi PBB, yaitu bahasa Arab, Bahasa China, Bahasa Inggris, Bahasa Perancis, Bahasa Rusia, dan Bahasa Spanyol. Selain itu, beberapa bahasa dengan pengguna yang cukup besar turut terlibat di awal proyek ini seperti bahasa Jepang, Bahasa Indonesia, bahasa Portugis, dan Bahasa Italia.

Universal Networking Language (UNL) sebenarnya merupakan pengembangan dari proyek MMTS sebelumnya dan merupakan bahasa formal deklaratif yang dirancang khusus untuk mewakili data semantik yang diekstraksi dari teks bahasa alami. UNL dapat digunakan sebagai bahasa pivot dalam sistem mesin penerjemah antar bahasa atau sebagai bahasa representasi pengetahuan dalam aplikasi pencarian informasi.

Secara ringkas, UNL intinya merupakan salah satu bentuk representasi Interlingua untuk sistem mesin penerjemah. Representasi dari UNL terdiri atas kosa kata yang merupakan kumpulan konsep UNL dan disebut dengan Universal Word (UW), relasi antar UW, dan atribut-atribut yang melekat di dalam suatu UW. Representasi semantis dari suatu kalimat dinyatakan dalam kumpulan tuple yang masing-masing tuple terdiri atas dua konsep atau UW dan relasi semantik dari kedua UW tersebut. Konsep-konsep di dalam tuple dapat mempunyai atribut sesuai dengan fitur semantiknya di dalam kalimat. Berikut adalah contoh representasi semantik dari kalimat bahasa Inggris I ran in the park yesterday.

$$
\begin{aligned}
& \text { \{org:el\}I ran in the park yesterday. }\{/ \text { org }\}\{\text { unl }\} \\
& \text { agt(run(icl>do).@entry.@past, i(icl>person)) } \\
& \text { plc(run(icl>do).@entry.@past, park(icl>place).@def) } \\
& \text { tim(run(icl>do).@entry.@past, yesterday) }\{/ \text { unl }\}
\end{aligned}
$$

Setiap negara yang bertanggunga-jawab terhadap bahasa $\mathbf{A}$ di dalam proyek ini berkewajiban untuk mengembangkan EnConverter bahasa A, DeConverter bahasa A, dan korespondensi antara kosa kata bahasa A dengan UW dari UNL. Di mana EnConverter merupakan sistem analisa dari suatu bahasa alami ke representasi UNL dan DeCOnverter merupakan sistem generasi dari representasi UNL ke dalam bahasa alami tertentu. Indonesia yang diwakili oleh BPPT di dalam proyek UNL, dalam hal ini 
harus mengembangkan EnConverter Bahasa Indonesia, DeConverter Bahasa Indonesia dan kamus elektronik Bahasa Indonesia yang katakatanya berkorespondensi dengan UW.

Proyek ini belum secara resmi berakhir, namun pada tahun 2001 dibentuk yayasan non profit untuk melanjutkan kegiatan proyek UNL. Yayasan yang bernama Universal Networking Digital Language Foundation ini berkedudukan di Jenewa, Swiss, dan bertujuan untuk mengembangkan dan mempromosikan UNL - Bahasa buatan yang dibuat untuk mereprentasikan informasi dan menghilangkan hambatan bahasa di seluruh dunia- .

\section{PAN Localization}

PAN Localization merupakan proyek kemitraan yang berinisiatif untuk membangun kapasitas dalam institusi regional di Asia Selatan dan Tenggara dalam hal komputasi bahasa lokal. Proyek yang didanai oleh International Development Research Center (IDRC), Kanada, ini mempunyai tiga tujuan utama yaitu:

a. mengembangkan kapasitas sumber daya manusia yang berkelanjutan di kawasan Asia untuk R\&D dalam teknologi bahasa lokal;

b. meningkatkan level dukungan teknologi untuk bahasa-bahasa Asia yang lebih kompleks dari bahasa Inggris;

c. memajukan kebijakan dalam pembuatan konten bahasa lokal dan akses di seluruh Asia untuk pengembangan aplikasi bahasa.

Proyek ini juga akan membangun jaringan peneliti Asia untuk berbagi pengalaman dan pengetahuan dan akan mempublikasikan hasil penelitian. Fase pertama proyek dimulai pada tahun 2004 dan berakhir pada tahun 2007.

Negara-negara (dan bahasa) yang termasuk dalam fase pertama ini adalah Afghanistan (Pashto, Dari), Bangladesh (Bangla), Bhutan (Dzongkha), Kamboja (Khmer), Laos (Lao), Nepal (Nepal) dan Sri Lanka (Sinhala, Tamil).

Pada fase kedua proyek yang dimulai dari tahun 2007 sampai dengan tahun 2010, beberapa negara Asia lainnya bergabung. Indonesia yang diwakili oleh BPPT dan Universitas Indonesia menjadi anggota baru proyek ini di samping beberapa negara dan bahasa baru lainnya seperti China, Mongolia, dan Bangladesh.

Sesuai dengan perkembangan teknologi mesin penerjemah saat itu yang mulai beralih dari metode berbasis aturan ke metode berbasis statistik yang memerlukan tersedianya korpus paralel, dalam proyek ini BPPT mulai mengumpulkan korpus paralel sebagai sumber daya kebahasaan utama dalam pengembangan mesin penerjemah. Perangkat lunak sistem manajemen korpus yang berfungsi untuk mengumpulkan dan membersihkan data telah dikembangkan dan dimanfaatkan untuk pengembangan korpus monolingual bahasa Indonesia dan korpus Paralel Bahasa Indonesia - Bahasa Inggris. Selain itu di dalam proyek ini dikembangkan juga aplikasi Part-of-Speech Tagger bahasa Indonesia 
untuk melabeli korpus monolingual bahasa Indonesia yang terbentuk dengan kelas kata bahasa Indonesia.

Dalam proyek ini BPPT telah berhasil mengumpulkan korpus paralel sebesar 500.000 kata dan korpus monolingual bahasa Indonesia yang telah dilabeli dengan kelas kata sebesar 1 juta kata. Sumber daya kebahasaan ini dapat diunduh melalui tautan sbb: http://www.pan110n.net/english/OutputsIndonesia2.htm. Prototipe mesin penerjemah bahasa Indonesia $\leftrightarrow$ bahasa Inggris berbasis statistik yang dikembangkan dengan perangkat lunak Moses dan menggunakan korpus yang telah dikumpulkan di atas telah terimplementasikan. Prototipe ini selanjutnya menjadi basis pengembangan sistem mesin penerjemah bahasa Indonesia $\longleftrightarrow \rightarrow$ bahasa Inggris berbasis statistik di kegiatan BPPT berikutnya.

\section{ASEAN MT}

Proyek ASEAN-MT bertema - Layanan Publik Terjemahan Bahasa ASEAN Berbasis Jaringan - dimulai pada bulan Juli tahun 2012, dan didukung oleh Sub-Committee on Microelectronics and Information Technology (SCMIT), ASEAN serta dukungan parsial dari ASEAN Science Fund (ASF). Proyek ini merupakan proyek mesin penerjemah untuk bahasa-bahasa utama di Asia Tenggara dan dilatarbelangai oleh rencana pembentukan komunitas ekonomi ASEAN di tahun 2015. Jika komunitas ekonomi ASEAN ini terwujud diperkirakan akan terjadi peningkatan lalu lintas antar negara ASEAN dan komunikasi antar warga negara yang berbeda bahasa. Untuk itu diperlukan mesin penerjemah untuk menghilangkan hambatan bahasa yang mungkin terjadi.

Beberapa institusi riset dan universitas terlibat di dalam proyek dan masing-masing institusi bertanggung jawab untuk menangani bahasa yang ada di wilayahnya. Insitusi yang terlibat dalam proyek ini adalah sbb:

a. Universiti Brunei Darussalam (UBD), Brunei

b. National Information Communications Technology Development Authority (NiDA), Kamboja

c. Agency for the Assessment and Application of Technology (BPPT), Indonesia

d. Computer Technology and Electronic Institute, Ministry of Science and Technology (MOST), Laos

e. Linton University College, Malaysia

f. University of Computer Studies, Yangon (UCSY), Myanmar

g. De La Salle University (DLSU), Filipina

h. Institute for Infocomm Research (I2R), Singapura

i. Institute of Information Technology (IOIT), Vietnam

j. National Electronics and Computer Technology Center (NECTEC), Thailand

Sesuai dengan perkembangan teknologi pada saat itu, ASEAN-MT mengunakan metode berbasis statistik dan perangkat lunak Moses. 20.000 kalimat bahasa Inggris dengan domain pariwisata dibuat sebagai perantara untuk membuat kalimat paralel dari setiap bahasa yang terlibat. Kamus Entitas Nama juga dikembangkan dan masing-masing institusi 
berkewajiban untuk membuat basis data yang berisi nama organisasi, nama orang, nama lokasi, atau nama lainnya yang terkait geografis di negaranya. Kalimat paralel yang terbentuk digunakan sebagai data latih dari perangkat lunak Moses untuk membuat model translasi dan model bahasa dari pasangan bahasa sumber dan bahasa target penerjemahan.

Sistem mesin penerjemah dari setiap bahasa dijalankan sebagai layanan web pada komputer server yang ada di setiap negara yang terlibat proyek. Server-server ini dihubungkan ke server layanan ASEAN MT yang berada di Bangkok melalui infrastruktur jaringan Language Grid (LanGrid) dan dapat diakses dengan alamat http://www.servicegrid-bangkok.org/ . Pengguna dapat mengakses layanan ini lewat web atau aplikasi-aplikasi mobile khusus.

\section{U-STAR}

Selama bertahun-tahun, penelitian dan studi tentang teknologi terjemahan wicata-ke-wicara (Speech-to-speech Translation - S2ST) telah dilakukan dengan tujuan untuk mengatasi hambatan bahasa di seluruh dunia yang sangat banyak jumlahnya. Sangat sulit untuk dapat membangun sistem S2ST yang mencakup semua topik dan bahasa, namun, dengan menghubungkan modul ASR, MT, dan TTS yang didistribusikan dari berbagai organisasi di seluruh dunia, diharapkan dapat dibangun sistem S2ST global yang memungkinkan untuk membebaskan hambatan bahasa ini.

Konsorsium U-STAR (Universal Speech Translation Advanced Research) yang merupakan transformasi dari konsorsium ASTAR (Asian Speech Translation Advanced Research) pada tahun 2010, berusaha untuk merealisasikan terciptanya suatu aplikasi penerjemah wicara-ke-wicara dari berbagai bahasa global. Untuk itu, konsorsium U-STAR dibentuk dengan 8 anggota awal yang salah satu di antaranya adalah BPPT yang berkewajiban untuk menangani modul-modul bahasa Indonesia yaitu pengenalan wicara Bahasa Indonesia, mesin penerjemah Bahasa Indonesia $\leftarrow$ Bahasa Inggris, dan pembangkit wicara bahasa Indonesia. Saat ini jumlah anggota U-STAR mencapai 30 institusi dari berbagai belahan dunia, dan masing-masing menangani bahasa yang berbeda.

Untuk menghubungkan modul-modul yang terdistribusi untuk bahasa dan fungsi yang berbeda secara andal, perlu untuk membakukan protokol komunikasi dan format data antar modul. Dalam hal ini konsorsium USTAR menggunakan rekomendasi ITU-T yaitu F.745 Functional Requirements for Network-based S2ST dan H.625 Architectual Requirements for Network-based S2ST yang disetujui pada 14 Oktober 2010. Dengan menggunakan standar-standar yang baku ini, layanan penerjemahan dari berbagai bahasa yang tersebar di berbagai institusi global dapat terlaksana dengan handal.

Layanan penerjemahan wicara-ke-wicara dari U-STAR dapat diakses menggunakan aplikasi UNITRANS. UNITRANS adalah aplikasi penerjemahan wicara berbasis Android yang dapat menerjemahkan wicara atau teks pengguna ke berbagai bahasa. UNITRANS mendukung 30 bahasa termasuk dialek, dan dapat diunduh secara gratis. Saat ini tersedia 
fitur-fitur aplikasi yang baru seperti antarmuka yang mudah digunakan, dan fungsi Simpan Frasa yang berguna untuk menyimpan frasa yang sering digunakan, beserta terjemahannya.

BPPT yang bertanggung jawab untuk menangani modul bahasa Indonesia sudah mempunyai sumber daya kebahasaan dan modulmodulnya dari proyek-proyek sebelumnya seperti modul pengenalan wicara Bahasa Indonesia, modul mesin penerjemah Bahasa Inggris $\leftarrow \rightarrow$ Bahasa Indonesia, dan modul pembangkit wicara Bahasa Indonesia. Dalam hal ini BPPT tinggal membuat ketiga modul tersebut ke dalam layanan web dan mengintegrasikannya ke dalam sistem U-STAR sesuai dengan standar yang telah ditentukan.

Beberapa proyek kerja sama riset dan pengembangan di atas memberikan pengalaman yang sangat berharga bagi BPPT di bidang pemrosesan bahasa alami dan juga menghasilkan sumber daya kebahasaan yang cukup banyak untuk dimanfaatkan dalam pengembangan aplikasi pemrosesan bahasa alami lainnya. Setelah beberapa proyek ini berakhir, di tahun 2015, BPPT telah berhasil mengumpulkan korpus paralel bahasa Inggris - bahasa Indonesia sebesar 250.000 kalimat dan korpus monolingual bahasa Indonesia sebesar 10 juta kalimat unik.

\section{Wordnet Bahasa Indonesia dan Asian Wordnet (AWN)}

Leksikon multibahasa adalah data yang paling penting untuk kaji terap teknologi bahasa, karena leksikon multibahasa digunakan untuk berbagai aplikasi multibahasa seperti Perjemahan Mesin, Parser, Kamus terminologi, dan antarmuka multibahasa lainnya.

WordNet adalah sumber yang digunakan untuk identifikasi fitur semantik yang dapat dikaitkan ke unit leksikal. WordNet merupakan program yang dikembangkan di Princeton University WordNet (PWN) dengan menggunakan kamus bilingual dan menjadi salah satu bank leksikal semantik bahasa Inggris yang berisi hubungan semantik antara kata-kata. Pemetaan konsep Synset adalah proses pengorganisasian kata yang membentuk hubungan yang bermakna di antara kata-kata (nouns, verbs, adjective dan adverbs).

Dalam rangka mengembangkan Wordnet Bahasa Indonesia [24] dibangun sistem manajemen basis data bahasa Indonesia yang merupakan basis data leksikal bahasa Indonesia yang terstruktur dalam kumpulan Asian Wordnet (AWN). AWN adalah upaya kolaborasi dalam menciptakan Wordnet yang saling berhubungan untuk bahasa-bahasa Asia, yang dilaksanakan oleh BPPT bersama dengan

- National Institute of Information and Communications Technology (NICT), Japan

- Thai Computational Linguistics Laboratory (TCL), Thailand

- National Electronics and Computer Technology Center (NECTEC), Thailand

- National University of Mongolia (NUM), Mongolia

- Myanmar Computer Federation (MCF), Myanmar

- National Authority of Science and Technology (NAST), Lao PDR

- Madan Puraskar Pustakalaya (MPP), Nepal 
- University of Colombo School of Computing (UCSC), SriLanka

- Vietnamese Academy of Science and Technology (VAST), Vietnam

Penelitian ini mengembangkan arsitektur layanan web yang berfokus pada lintas bahasa Asia yang didistribusikan kepada pengguna melalui pendekatan kecerdasan kolektif (collective intelligence) untuk membangun Wordnet bahasa yang setara dengan PWN.

Combined Bahasa Wordnet selanjutnya melakukan pengembangan semua hubungan (hypernym, meronim) berasal dari Princeton WordNet 3.0. Kami telah memperkaya synset (keselarasan) dengan lemma Indonesia dan Melayu, yang terdiri dari 49.668 synset, 145.696 sense, 64.431 kata unik [25].

\section{B. Pengenalan Wicara}

Riset dan Pengembangan aplikasi pengenalan wicara Bahasa Indonesia oleh BPPT mulai dilakukan pada tahun 2008. Pada awal riset, aplikasi pengenalan wicara Bahasa Indonesia hanya dibuat untuk mengenali kata-kata tertentu saja yaitu perintah-perintah yang ada di dalam sistem operasi Linux. Aplikasi yang disebut dengan ILVC (Indonesian Linux Voice Command) ini dimaksudkan untuk membantu orang-orang berkebutuhan khusus seperti orang yang penglihatannya kurang atau buta agar dapat mengoperasikan komputer dengan suara. ILVC dikembangkan menggunakan perangkat lunak HTK dan hanya dapat mengenali perintah-perintah Linux yang telah dilatihkan ke dalam sistem.

Pada tahun 2009, ILVC dikembangkan lebih lanjut ke dalam aplikasi yang dinamai LiSan (Linux dengan liSan). LiSan adalah Sistem Pengenalan Wicara Bahasa Indonesia untuk perintah komputer dan penulisan dokumen dalam OS Linux yang dikembangkan bagi penyandang cacat agar dapat menggunakan piranti komputer melalui instruksi suara. Jadi ada penambahan fitur penulisan dokumen dari aplikasi ILVC sebelumnya. Pengguna LiSan dalam hal ini sudah dapat melakukan transkripsi dalam membuat suatu dokumen. Kata-kata yang tercakup juga lebih luas dan tidak terbatas pada kata-kata perintah Linux. Perangkat lunak pengenalan wicara yang digunakan juga masih sama dengan yang digunakan ILVC yaitu HTK.

BPPT mulai melakukan riset pengenalan wicara dengan lebih serius dan bekerja sama dengan PT INTI untuk mengembangkan perangkat lunak Perisalah yang berkemampuan mencatat segala bentuk pembicaraan, pidato dan lainnya dengan cepat dan akurat langsung dalam bentuk tulisan. Perangkat lunak ini utamanya digunakan untuk mentranskripsikan pembicaraan rapat dan meringkasnya dalam bentuk notulensi yang lebih ringkas.

Pada tahap awal pengembangan, dilakukan perekaman data wicara dari 400 orang yang terdiri dari 200 pria dan 200 wanita, dan masing-masing mengucapkan 250 kalimat ujaran. Para pengujar ini dipilih dari beberapa etnis di Indonesia dan masih mempunyai dialek daerah masing-masing dalam mengucapkan kalimat bahasa Indonesia. Dengan demikian hasil pengenalan wicaranya dapat menangani berbagai dialek di Indonesia. Data wicara yang terbentuk ini selanjutnya digunakan sebagai data latih untuk membuat model akustik dari sistem pengenalan wicara yang dibangun.

Perisalah menggunakan enjin pengenalan wicara Julius yang terkenal cukup handal pada saat itu. Dalam implementasinya, perisalah dibuat berbasis model 
bahasa dengan trigram (3-gram) kata dan Hidden Markov Model (HMM). Model bahasa ini dihasilkan dari data korpus monolingual bahasa Indonesia yang dikumpulkan oleh BPPT dari berbagai situs web dan buku.

Perangkat lunak Perisalah telah dikomersialkan oleh mitra pengembang BPPT yaitu PT. INTI dan telah dipasang dan digunakan di berbagai instansi seperti MK, DPR,dll. Penggunaan Perisalah ini terbukti dapat mempercepat pembuatan notulensi dari rapat-rapat yang berlangsung di instansi pengguna.

Riset tentang pengenalan wicara di BPPT tetap berlangsung walaupun telah terbentuk produk yang komersial. Pembuatan data wicara tetap dilakukan secara mandiri untuk dapat meningkatkan akurasi sistem. Munculnya enjin pengenalan wicara yang baru dan lebih handal dari Julius juga dikaji dan dicoba diimplementasikan menggunakan data wicara yang telah terbentuk. Sampai saat ini BPPT telah berhasil menambah data wicara sebesar 50 kalimat ujaran yang direkam dari 50 pria dewasa, 50 pria remaja, 50 wanita dewasa, dan 50 wanita remaja yang masing-masing mengucapkan 250 kalimat.

Saat ini sistem pengenalan wicara di BPPT menggunakan framework Kaldi. Kaldi menyediakan beberapa recipe pengolahan data suara untuk menjadi model yang dapat digunakan untuk sistem pengenal wicara. Dalam hal ini BPPT telah mencoba membandingkan kombinasi recipe Kaldi yang tersedia saat ini terhadap data wicara yang dimiliki BPPT. Hasil dari percobaan ini diperoleh kombinasi recipe yang paling optimum yaitu menggunakan Graph-tri3b + TDNN (nnet3/tdnn_1) $)^{2}$ yang dalam percobaannya menghasilkan Word Error Rate (WER) $1,64 \%$ dan Sentence Error Rate (SER) 10,16\%.

\section{Pembangkit Wicara}

Sistem pembangkit wicara Bahasa Indonesia mulai dikembangkan di BPPT sejak tahun 2001. Saat itu metode yang digunakan adalah diphone concatenation. Diphone merupakan pasangan fonem yang berdekatan dan pembangkitan ujaran dari suatu kata dapat dilakukan dengan menggabungkan komponen-komponen diphone dari kata tersebut. Perangkat lunak Mbrola digunakan untuk membangun pembangkit wicara Bahasa Indonesia karena hasil sintesis Mbrola dianggap lebih tinggi kualitasnya daripada sintesis dari sebagian besar perangkat lunak lainnya yang berbasis diphone. Hal ini dapat dihasilkan karena Mbrola memproses ulang diphones sehingga memaksakan pitch konstan dan fase harmoniknya untuk meningkatkan kualitas penggabungannya sementara sedikit menurunkan kualitas segmentalnya.

Basis data diphone bahasa Indonesia yang dibuat oleh Arry Akhmad Arman dari ITB telah tersedia di laman web Mbrola, sehingga BPPT tidak perlu membuatnya lagi. Dalam hal ini, BPPT tinggal mengembangkan prosody bahasa Indonesia agar suara yang dihasilkan tidak menyerupai suara robot. Dengan tambahan prosody ini, wicara yang dibangkitkan mempunyai irama, penekanan, dan intonasi sehingga hasilnya lebih natural.

Setelah aplikasi berbasis Mbrola terbentuk, riset dan pengembangan pembangkit wicara di BPPT kurang berkembang dan mulai dibangun lagi pada tahun 2015 seiring dengan kebutuhan pengembangan sistem penerjemah wicarake-wicara yang dipicu oleh keterlibatan BPPT dalam proyek U-STAR. Sesuai 
dengan teknologi yang paling mutakhir saat itu, dipilihlah metode end-to-end dengan enjin Tacotron model Keithito untuk pengembangan pembangkit wicara bahasa Indonesia yang menggunakan metode deep learning.

Data wicara untuk data latih pembangkit wicara bahasa Indonesia saat itu belum tersedia. Untuk itu dilakukan perekaman terhadap 1 orang wanita dewasa dan 1 orang pria dewasa yang masing-masing mengujarkan 5.000 kalimat bahasa Indonesia. Data ini kemudian digunakan sebagai data latih dari enjin Tacotron model Keithito untuk membuat model pembangkit wicara bahasa Indonesia. Hasil pembangkitan wicara dengan metode end-to-end ini jauh lebih alami dibandingkan dengan hasil dari metode diphone concatenation dengan Mbrola yang dikembangkan sebelumnya. Pengujian hasil sintesis suara secara subjektif untuk aspek naturalness dengan skala $1-5$ diperoleh nilai 3 untuk suara pria dan 3 untuk suara wanita.

Data 5.000 ujaran untuk pengembangan pembangkit wicara adalah sangat minim sehingga perlu dilakukan perekaman data wicara lagi. Terkait hal ini perekaman data wicara terhadap 1 wanita dewasa dan 1 pria dewasa yang masing-masing mengucapkan 15.000 kalimat ujaran, dilakukan untuk memperbaiki kualitas sintesis wicaranya. Durasi data yang dihasilkan adalah 21 jam suara pria dan 24 jam suara wanita. Data wicara inilah yang dijadikan sebagai data utama BPPT dalam pengembangan pembangkit wicara Bahasa Indonesia. Data ini telah digunakan sebagai data latih untuk membuat model Tacotron pada tahun 2017 dan dari pengujian hasil sintesisnya diperoleh aspek naturalness diperoleh nilai 3.5 untuk suara pria dan 4 untuk suara wanita, sedangkan untuk aspek intelligibility secara subjektif diperoleh WER 64,63\% untuk suara pria dan WER $71,28 \%$ untuk suara wanita.

Tacotron dapat menghasilkan suara sintesis yang cukup natural, tetapi proses sintesanya cukup lama dan memerlukan mesin yang menggunakan GPU. Pada tahun 2018 dan 2019, tim BPPT mencoba menggunakan enjin pembangkit wicara Merlin yang menggunakan metode parametrik statistik dengan data wicara yang sama. Hasil yang diperoleh tidak sebaik hasil sintesis yang menggunakan Tacotron model Keithito sehingga pada akhir tahun 2019 dicoba diproses lagi menggunakan Tacotron model Mozilla. Hasil sintesis menggunakan enjin Mozilla TTS sekilas lebih baik dibandingkan dengan Tacotron model Keithito tetapi sampai saat belum diuji dari aspek naturalness dan intelligibility-nya.

\section{Sistem penerjemah Wicara-ke-wicara mobile berbasis Android}

Berbekal sumber daya kebahasaan dan pengalaman yang dimiliki BPPT dalam pengembangan beberapa aplikasi NLP, pada tahun 2015 dimulailah pengembangan penerjemah wicara-ke-wicara atau S2ST (Speech-to-Speech Translation) bahasa Inggris $\leftarrow \rightarrow$ bahasa Indonesia secara mandiri. Secara umum layanan setiap modul dijalankan di dalam server khusus dan aplikasi klien berbasis Android untuk mengakses layanan. Aplikasi klien berbasis Android dipilih karena sebagian besar pengguna perangkat mobile saat ini didominasi oleh pengguna perangkat Android .

Modul-modul utama dari sistem penerjemah wicara-ke-wicara sudah dimiliki oleh BPPT sehingga kegiatan pengembangan lebih ditekankan pada perancangan 
protokol komunikasi dan bagaimana protokol tersebut digunakan dan juga pembuatan aplikasi klien di perangkat Android dengan mengikuti protokol komunikasi yang telah ditetapkan. Namun, karena modul-modul utama sistem penerjemah wicara-ke-wicara yaitu pengenalan wicara, mesin penerjemah Bahasa Inggris $\leftarrow \rightarrow$ Bahasa Indonesia, dan pembangkit wicara belum optimal kinerjanya, dilakukan kegiatan untuk meningkatkan dan mengoptimalkan modul-modul tersebut. Secara ringkas, optimalisasi modul-modul tersebuat adalah sebagai berikut:

a. Modul pengenalan wicara atau ASR (Automatic Speech Recognition)

Optimalisasi modul pengenalan wicara dilakukan dengan memeriksa ulang kesesuaian antara data wicara dengan kalimat yang diujarkan. Pemeriksaan ini dilakukan karena jika masih terdapat kesalahan korespondensi antara data wicara dan kalinat yang seharusnya diucapkan dapat mengurang akurasi pengenalannya . Hal berikutnya yang dilakukan adalah mencoba berbagai recipe Kaldi dan menguji hasilnya dan selanjutnya dipilih recipe yang paling optimal. Hasil pengujian ini akhirnya ditetapkan untuk menggunakan recipe nnet2 untuk implementasi modul pengenalan wicara Bahasa Indonesia.

b. Modul Mesin penerjemah atau MT (Machine Translation)

Optimalisasi modul mesin penerjemah dilakukan dengan cara penambahan korpus paralel dan metode mesin penerjemah yang digunakan. Penambahan korpus paralel dilakukan dengan cara mengekstrak kalimat-kalimat paralel dari situs-situs bilingual, majalah atau buku bilingual, dan juga kalimat percakapan yang diambil dari subtitle film yang menyediakan subtitle dalam bahasa Inggris dan bahasa Indonesia. Dari pemrosesan ini dapat diperoleh sekitar 10 juta kalimat paralel dan 6,3 juta kalimat percakapan paralel. Perangkat lunak yang digunakan juga diubah dari yang sebelumnya menggunakan metode statistik dengan Moses, kemudian diubah dengan metode sequence-to-sequence menggunakan perangkat lunak OpenNMTpy . Pada akhir kegiatan telah dicoba diimplementasikan fitur transformer pada enjin OpenNMT-py. Pengukuran akurasi hasil pengembangan mesin penerjemah dengan bleu score memberikan hasil 57.92 untuk Bahasa Indonesia ke Bahasa Inggris dan 71.17 untuk Bahasa Inggris ke Bahasa Indonesia.

c. Modul pembangkit wicara atau TTS (Text-to-Speech)

Modul pembangkit wicara dioptimalkan dengan menggunakan enjin Mozilla TTS dan diperoleh hasil sintesis yang lebih natural.

Server penerjemah wicara-ke-wicara diimplementasikan sebagai sebuah aplikasi JEE (Java Enterprise Edition) berbasis Spring Platform. Pemilihan Spring Platform ditetapkan karena salah satunya sudah mendukung WebSocket, RESTful Client/Server dan Message Queue. Implementasi server S2ST dan layanan pendukungnya berupa ASR, MT dan TTS dijadikan docker image. Dengan menjadikan S2ST server dan layanan pendukungnya menjadi docker image, maka tiap-tiap komponen akan dapat dijalankan sebagai docker container di atas container engine dan dapat dipantau dan dikendalikan dengan lebih mudah melalui aplikasi web seperti portainer. 
Untuk dapat berfungsi sebagai sebuah layanan S2ST yang terintegrasi dibutuhkan koneksi antara S2ST server dan layanan pendukungnya. Rancangan koneksi tersebut bisa digambarkan sebagai berikut:

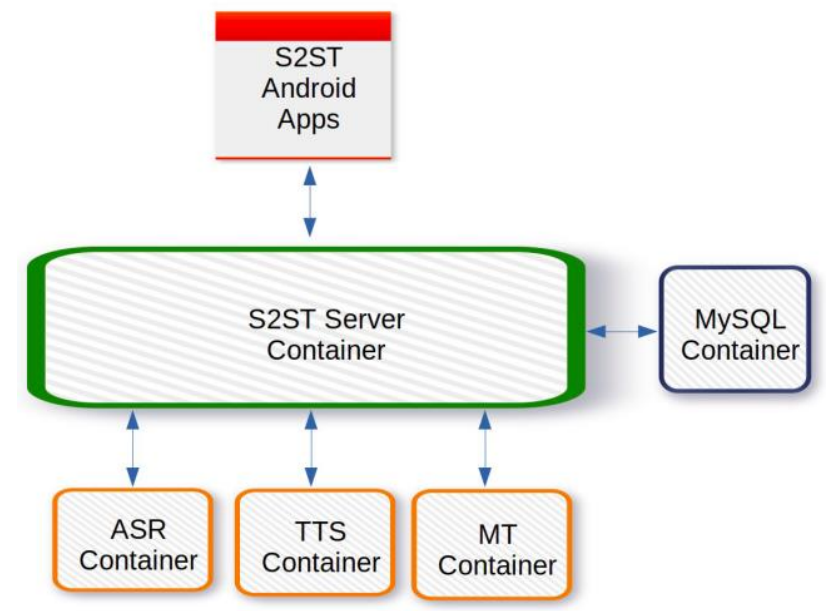

Gambar 1 Rancangan koneksi antara S2ST server dan layanan pendukung

Penjelasannya adalah sebagai berikut:

- S2ST server container akan menjadi container yang dapat dijangkau oleh aplikasi S2ST Mobile berbasis Android melalui HTTP, WebSocket dan layanan RESTful

- S2ST server akan terhubung ke container ASR melalui HTTP dan WebSocket

- S2ST server akan terhubung ke container MT dan TTS melalui HTTP, layanan RESTful dan ActiveMQ.

- S2ST server akan terhubung ke containe MySQL yang memberi layanan basis-data

Aplikasi klien S2ST berbasis android mengimplementasikan modul voice activity detection (VAD) untuk mendeteksi kondisi silence sehingga hanya data wicara yang dikirimkan ke server S2ST. Selebihnya aplikasi mengikuti protokol komunikasi yang telah didesain untuk dapat menerima masukan data wicara dari pengguna, mengirim data wicara ke server S2ST, menerima teks hasil pengenalan wicara, mengirim teks ke layanan MT, mengirimkan teks terjemahan ke layanan TTS, dan menerima data wicara hasil dari layanan TTS.

Prototipe sistem penerjemah Wicara-ke-wicara mobile berbasis Android ini telah diuji dalam skala laboratorium dengan menggunakan jaringan lokal di dalam laboratorium. Dalam kondisi ruangan yang tidak ramai, sistem dapat berjalan dengan stabil mulai dari menerima masukan wicara pengguna melalui perangkat Android dengan bahasa sumber Bahasa Indonesia sampai diterimanya wicara dari kalimat terjemahannya di perangkat Android lainnya dalam bahasa Inggris. Demikian juga sebaliknya dari bahasa Inggris ke Bahasa Indonesia.

Berikut tampilan dari aplikasi klien penerjemah wicara-ke-wicara berbasis Android.: 


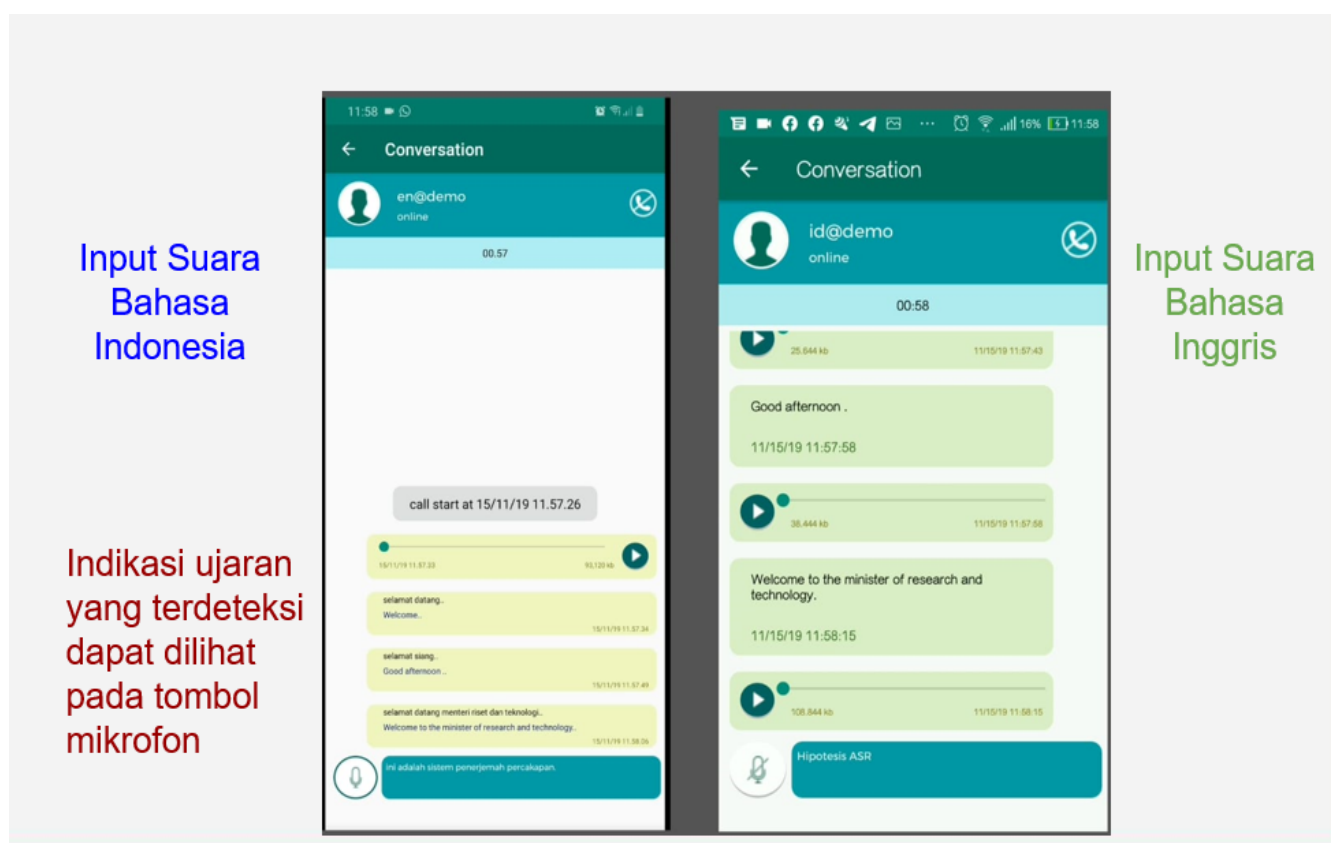

Gambar 2 Tampilan aplikasi klien penerjemah wicara-ke-wicara berbasis Android

\section{E. Pengembangan alat diagnosis Malaria dari citra mikroskopis apusan darah}

Pusat Teknologi Informasi \& Komunikasi BPPT selama ini telah menjalin kerjasama penelitian yang cukup intensif dengan laboratorium Malaria, Lembaga Biologi Molekuler Eijkman. Kerjasama penelitian tersebut bertujuan mengembangkan sistem diagnosis berbasis komputer, yang mengimplementasikan algoritma AI untuk menentukan status pasien Malaria, apabila positif terkena Malaria, dilanjutkan dengan identifikasi spesies dan fase hidup plasmodia yang menyerang sel darah merah. Malaria merupakan salah satu penyakit tropis yang hingga kini masih cukup banyak ditemukan di Indonesia, khususnya Indonesia bagian Timur. Di Indonesia, penderita Malaria diperkirakan berkisar 15 juta, dengan angka kematian 30 ribu per tahun. Data Annual Malaria Incidence menunjukkan bahwa Papua dan Nusa Tenggara Timur menempati peringkat atas dengan tingkat keterjangkitan 50-200 pada tahun 2006. Penyakit Malaria disebabkan oleh infeksi plasmodia dalam darah. Parasit ini terdiri dari 5 spesies: Plasmodium vivax, Plasmodium falciparum, Plasmodium ovale, Plasmodium malariae dan Plasmodium knowlesi.

Penyakit Malaria diindikasikan dari berbagai gejala seperti menggigil, demam tinggi, sakit kepala, anemia dan pembesaran limfa. Diagnosis dini merupakan langkah yang sangat penting agar pasien yang terindikasi terkena Malaria dapat ditangani dengan cepat. Dari berbagai jenis diagnosis Malaria yang dikenal (Rapid Diagnostic Test, Polymerase Chain Reaction), pemakaian mikroskop untuk menemukan keberadaan parasit plasmodia pada sel darah merah dari apusan darah telah diterima sebagai gold standard, dan telah dipakai luas di lapangan. Tetapi akurasi diagnosis ini sangat tergantung pada pengalaman dan keahlian microscopist (sebutan bagi ahli yang melakukan diagnosis lewat mikroskop). Terlebih lagi, dalam kegiatan Mass Blood Survey (MBS) yang dilakukan di 
daerah endemi Malaria, beban microscopist menjadi sangat berat. Slide yang diperiksa sangat banyak (ratusan), sedangkan untuk tiap slide harus diteliti dengan seksama dengan mikroskop, sel demi sel darah merah pada ratusan bidang pandang (titik pengamatan) pada slide yang diamati, untuk memastikan tidak adanya parasit plasmodia pada darah pasien. Apalagi di daerah pedalaman, microscopist yang telah berpengalaman sangat langka sehingga proses diagnosis menjadi lama dan tidak efektif.

Upaya untuk mengembangkan prototipe Computer Aided Diagnosis telah dilakukan dalam beberapa tahun terakhir. Sistem yang dikembangkan memakai apusan darah tipis, yang secara visual lebih informatif untuk memastikan keberadaan parasit pada sel darah merah [6]-[9]. Akan tetapi tingkat densitas darah pada apusan tipis jauh lebih rendah dibandingkan apusan tebal, sehingga kemungkinan untuk menemukan parasit jauh lebih kecil dibandingkan dengan apusan darah tebal. Hal ini mengakibatkan proses pencarian memerlukan waktu yang cukup lama, dengan memindahkan titik observasi pada slide ke posisi lain untuk mendapatkan bidang pandang yang lain.

Sistem yang dikembangkan memanfaatkan apusan darah tebal. Berbeda dengan apusan darah tipis yang hanya satu lapis saja, apusan darah tebal merupakan gumpalan darah yang lebih tebal dan berlapis-lapis. Sehingga pada luas bidang pandang yang sama, kemungkinan ditemukanya parasit jauh lebih besar dan adakalanya ratusan kali dibandingkan pada apusan tipis. Dengan mengolah data yang kandungan informasinya lebih besar, diharapkan proses deteksi parasit pada pasien dapat berlangsung lebih akurat dan cepat.

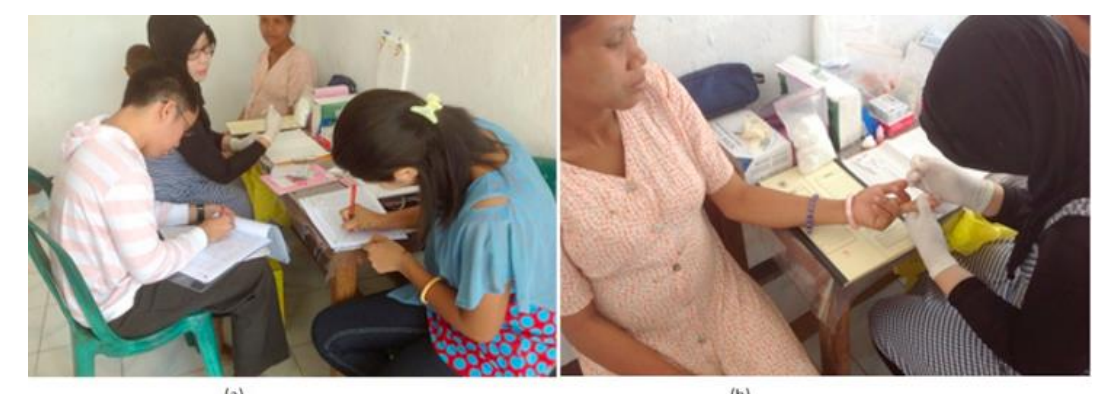

(b)
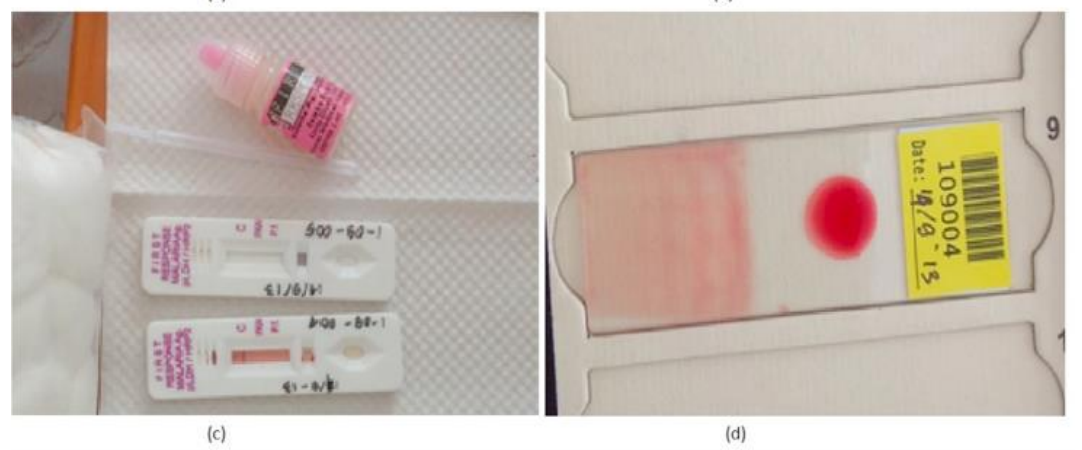

Gambar 3 Pengambilan data darah di Polindes Noha, Kabupaten Sumba Barat Daya.

(a) interview dengan pasien (b) pemeriksaan dengan Rapid Diagnostic Test (RDT), pembuatan slide dan sampel untuk analisa Polymerase Chain Reaction (PCR) (c) RDT yang digunakan untuk memeriksa pasien (d) apusan tipis dan tebal darah 


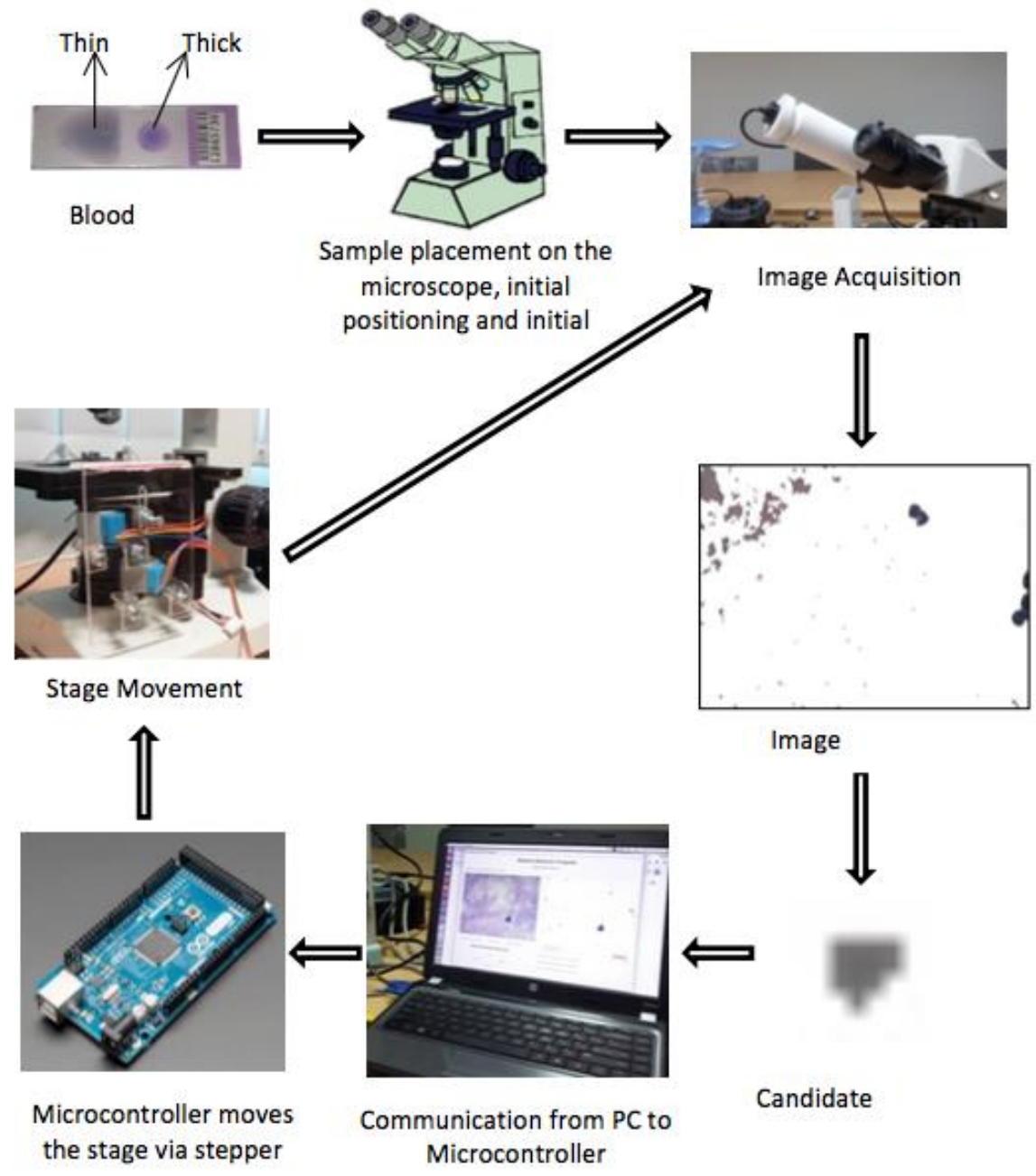

Gambar 4 Sistem Computer Aided Diagnosis Malaria apusan darah tebal

Gambar 4 menggambarkan rancangan umum dari Sistem CAD Malaria Apusan Darah Tebal yang sedang dikembangkan. Proses diagnosa dimulai dari pembacaan slide apusan darah tebal pada bidang pandang pertama (lokasi bidang pandang pertama yang diamati biasanya ujung kiri atas). Setelah ditangkap kamera, citra diolah oleh aplikasi untuk menentukan ada tidaknya parasit malaria di sana. Citra kemudian disimpan sebagai data. Setelah selesai, sistem kontrol motor akan menggeser slide (menggeser stage) ke kanan sedemikian rupa sehingga akan diperoleh bidang pandang kedua yang bersebelahan dengan yang pertama. Proses selanjutnya adalah pengambilan citra bidang pandang kedua untuk dianalisa dan disimpan. Proses ini terus diulangi sampai jumlah minimal bidang pandang (menurut SOP yang berlaku) yang didiagnosa, tercapai [10].

Alur pemrosesan citra dalam sistem yang dibangun terdiri dari lima bagian: (i) preprocessing (image enhancement) (ii) blood component segmentation (iii) feature extraction (iv) blood component classification (v) decision. Flowchart sistem ini ditampilkan pada Gambar 5. 


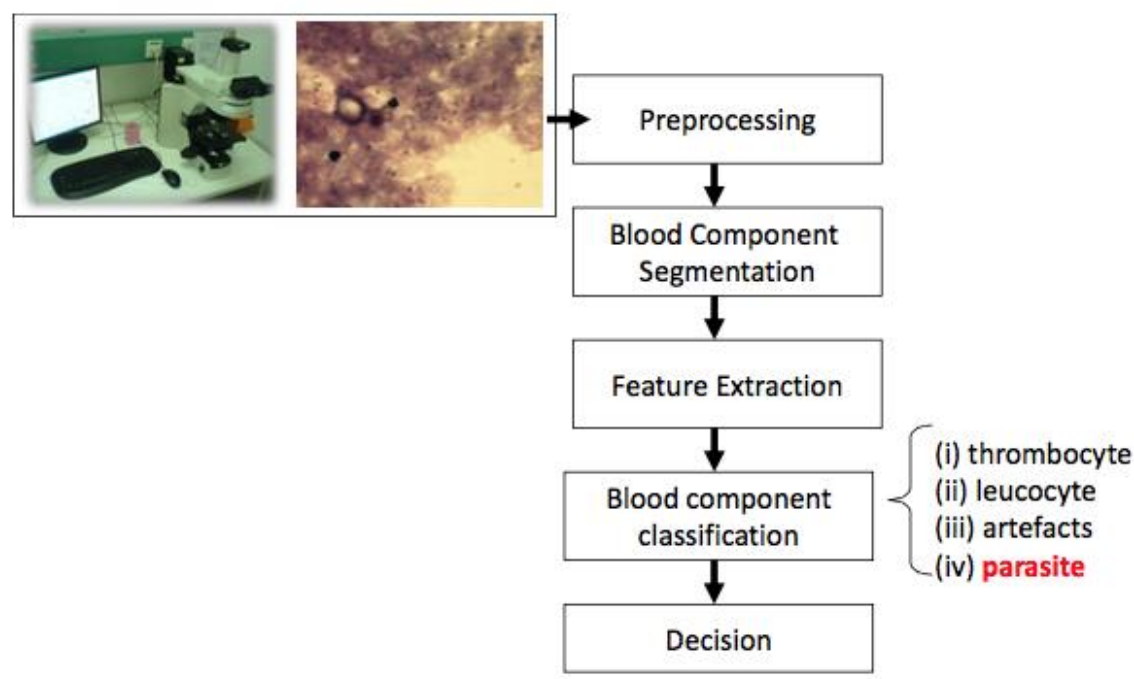

Gambar 5 Flowchart proses identifikasi parasit dari citra mikroskopis apusan darah tebal

Slide darah pasien ditempatkan di bawah mikroskop, dan selanjutnya dilakukan akuisisi citra pada bidang pandang tertentu pada apusan tebal. Citra yang diakuisisi selanjutnya diproses oleh bagian image enhancement. Image enhancement terdiri dari serangkaian tahap untuk menghapus noise, mengatur contrast, dan proses yang lain untuk membuat agar citra input menjadi lebih informatif dan mudah diproses oleh tahap berikutnya. Blood component segmentation berfungsi untuk mengisolasi object yang diperkirakan kandidat parasit dari background. Bagian ini merupakan bagian paling penting, karena harus mampu mengisolasi inti sel darah putih (leucocyte), parasit, thrombocyte maupun artefact dari apusan tebal. Pada tahap ketiga, object yang telah diisolasikan tersebut dilakukan ekstraksi fitur berdasarkan ciri morfologinya. Tahap keempat, adalah klasifikasi untuk menentukan apakah object tersebut parasit, nukleus sel darah putih, trombosit atau artefact. Tahap pertama hingga keempat ini dilakukan berulang-ulang untuk berbagai bidang pandang (titik observasi) dari citra mikroskopis apusan darah tebal. Tahap kelima adalah pengambilan keputusan status pasien, dari hasil analisis pada berbagai bidang pandang. Studi mengenai pengembangan algoritma ini dipublikasikan pada [11][15].

\section{F. Pengembangan Sistem Identifikasi berbasis multimodal biometrik}

KTP Elektronik atau KTP-el merupakan program pemerintah yang didukung oleh Kementrian Dalam Negeri, BPPT, dan berbagai instansi pemerintah yang lain untuk merealisasikan amanat Undang-Undang. Yang menjadi dasar hukumnya adalah Undang-Undang Administrasi Kependudukan No. 23 Tahun 2006 Pasal 64 Ayat 3 yang menyatakan bahwa "Dalam KTP sebagaimana dimaksud pada ayat (1) disediakan ruang untuk memuat kode keamanan dan rekaman elektronik pencatatan Peristiwa Penting". Kode keamanan adalah alat 
identifikasi jati diri yang menunjukan identitas diri penduduk secara tepat dan akurat sebagai autentikasi diri yang memastikan dokumen kependudukan sebagai milik orang tersebut.

Tujuan penerapan KTP elektronik adalah untuk mewujudkan dokumen identitas penduduk yang tunggal dan absah melalui proses identifikasi ketunggalan sidik jari secara terpusat (nasional), dan penyimpanan dan pengamanan data dengan menggunakan chip. Teknologi yang menjadi kunci utama dalam KTP-el adalah biometrik. Biometrik adalah salah satu teknologi yang dewasa ini makin meningkat intensitas pemanfaatan maupun penelitiannya. Teknologi biometrik didefinisikan sebagai berikut: "Biometric technologies are automated methods of verifying or recognizing the identity of a living person based on a physiological or behavioral characteristics" [16][17].

Dalam pelaksanaan program KTP-el di Indonesia, untuk menjamin ketunggalan identitas penduduk, tiga jenis modality (identifier) yang dipakai dalam elektronik KTP: sidik jari, iris dan wajah. Akan tetapi, teknologi KTP-el yang dipakai saat ini adalah teknologi dari prinsipal luar negeri, dimana pemerintah harus membelanjakan devisa negara secara berkala untuk membeli teknologi tersebut pada saat data biometrik ini harus diperbarui. Industri Dalam Negeri hingga kini belum mampu untuk menyediakan teknologi ini, karena kurangnya R\&D di bidang biometrik. BPPT sebagai Lembaga Pemerintahan Non Kementrian yang bergerak pada Pengkajian dan Penerapan teknologi memiliki peran sebagai perintis tumbuhnya industri dalam negeri yang kelak akan memenuhi kebutuhan negara di bidang teknologi biometrik. Untuk itu diperlukan studi awal dan pengembangan prototipe sebagai langkah pertama untuk penguasaan teknologi biometrik ini. Hasil yang diperoleh kelak dikembangkan lebih lanjut lewat kemitraan dengan industri dalam negeri agar dapat diproduksi pada level komersial dan skala besar.

Salah satu kegiatan yang kami lakukan, difokuskan pada penelitian dan pengembangan sistem identifikasi berbasis iris. Iris atau selaput pelangi pada mata manusia merupakan bagian yang berwarna yang tampak pada bola mata. Bagian iris terlihat sebagai lingkaran yang melingkupi bagian hitam pupil dengan warnawarna tertentu. Secara anatomi iris merupakan sebuah organ internal yang dilindungi, terletak di belakang kornea dan aqueous humour, serta berada di depan lensa mata.

Sebagai modality biometrik, iris memiliki beberapa kesamaan karakteristik dengan sidik jari, yaitu random morphogenesis. Pola tekstur iris adalah stochastic atau bisa juga chaotic. Dua orang yang kembar identik memiliki pola iris yang berbeda. Iris mata dan kanan pada orang yang sama pun berbeda, karena tidak ada pengaruh genetik pada pembentukan pola iris. Di sisi lain, iris memiliki kelebihan dibandingkan sidik jari:

- Terisolasi dan terlindung dari lingkungan eksternal

- Upaya untuk memodifikasi iris selalu diiringi dengan resiko membahayakan indra penglihatan 
- Merespon secara langsung rangsangan dari cahaya, sehingga secara alami bisa diuji apakah iris tersebut asli atau artifisial

- Pengambilan iris tidak memerlukan kontak dengan iris. Bahkan dari jarak $1 \mathrm{~m}$ sekalipun masih bisa terambil dengan baik.

- Intrinsic polar geometry

- High level randomness: 250 degree of freedom, entropy (information density) berkisar 3.2bits/mm2

Dewasa ini, iris sudah cukup banyak dipakai sebagai salah satu identifier biometrik. Evaluasi terhadap performa Iris untuk biometrik antara lain diselenggarakan pada tahun 2006 [18]. Kompetisi yang dinamakan ICE 2006 (Iris Challenge Evaluation) oleh The National Institute of Standards and Technology (2006). Algoritma yang diujikan berasal dari tiga vendor Sagem-Iridian, Iritech, dan Cambridge. Sampel yang diujikan sebanyak 59,558 (29,056 iris mata kanan dan 30,502 iris mata kiri) dari 240 subjects dengan 30 partisi untuk tiap mata. Hasil terbaik dicapai oleh Sagem-Iridian, dengan median FRR 0.012 pada FAR $0.001[19]$.

Arsitektur Iris Recognition System ditampilkan pada Gambar 6. Iris localization dan segmentation akan mengekstrak bagian iris dari mata, yang hasilnya ditampilkan pada Gambar 7 dalam bentuk donat. Selanjutnya Iris unwrapping akan mengubah bentuk donat tersebut menjadi segi empat.

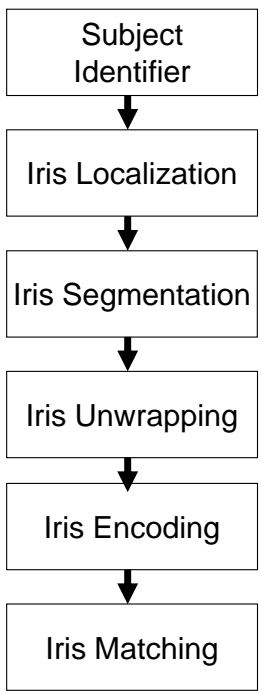

Gambar 6 Arsitektur Iris Recognition System

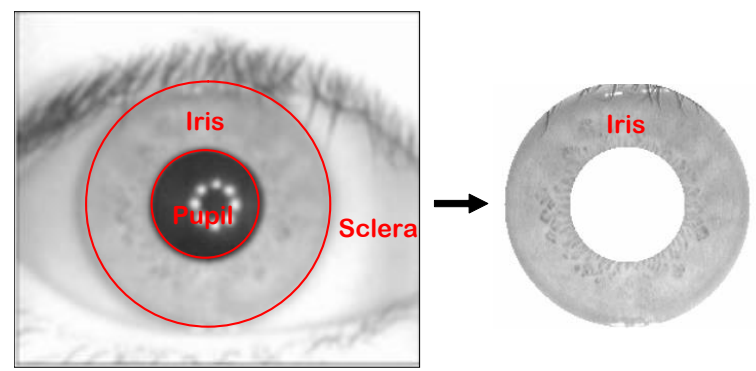


Gambar 7 Proses Iris localization \& segmentation

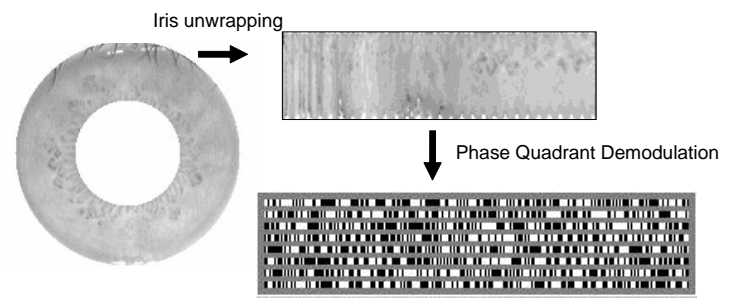

Gambar 8 Iris unwrapping dan Iris Code generation memakai Phase Quadrant Demodulation

Tahap terakhir adalah Iris Code generation memakai Phase Quadrant Demodulation, sehingga di peroleh binary code yang merepresentasikan keunikan individu. Iris code inilah yang kemudian dipakai untuk proses matching memakai Hamming distance sebagaimana ditampilkan pada persamaan (1).

$$
\mathrm{HD}_{\text {raw }}=\frac{\|(\text { code } \mathrm{A} \otimes \operatorname{code} \mathrm{B}) \bigcap \text { mask } \mathrm{A} \bigcap \text { maskB } \|}{\| \operatorname{maskA} \bigcap \text { maskB } \|}
$$

Dalam tiap fase pengembangan, dilakukan evaluasi kinerja sistem dengan memplot Receiver Operating Characteristic (ROC) curve dan Detection-Error Tradeoff curve. Pengembangan iris recognition system ini mengikuti alur yang dibangun oleh Daugman [9], dan dilakukan perbaikan pada sisi segmentasi dengan memakai Circular Hough Transform and Horizontal Projection Folding [21]-[23].

Evaluasi dilakukan memakai data yang dipakai berasal dari Malaysia Multimedia University Iris Image Database version 1 (MMU1). Citra iris direkam memakai LG IrisAccess ${ }^{\circledR}$, dengan semi-automatic camera yang dioperasikan pada jarak 7-25 cm. Kontributor terhadap data tersebut berasal dari berbagai kebangsaan dan usia. Tiap orang dilakukan perekaman sebanyak 5 citra iris tiap mata, berukuran 320x240 pixel. Gambar 9 menampilkan grafik False Match Rate (FMR) vs False Non Match Rate (FNMR) dari 40 iris dari database, sehingga diperoleh 1560 impostor matching score dan 40 genuine matching score.

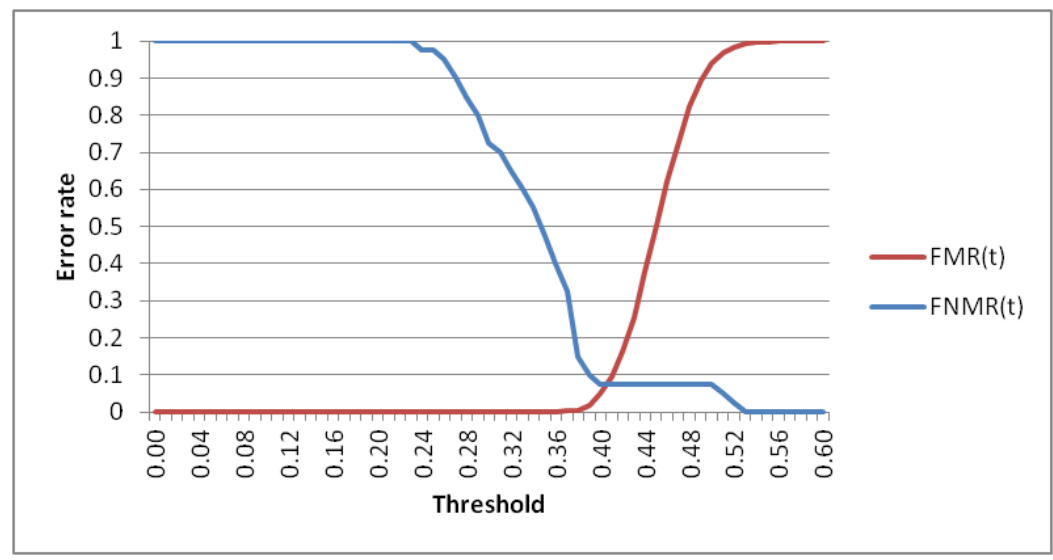


Gambar 9 Grafik FMR (False Match Rate) vs FNMR (False Non Match Rate) eksperimen matching iris dengan $\mathrm{N}=40$

\section{G. Pembuatan Standar Pertukaran Data Biometrik}

Standar Nasional Indonesia (SNI) adalah satu-satunya standar yang berlaku secara nasional di Indonesia. Dengan SNI diharapkan produk teknologi memenuhi spesifikasi teknis yang terstandarkan, sehingga konsumen yakin bahwa produk yang dipakainya efektif dan aman. Perumusan SNI harus memenuhi WTO code of good practice yang meliputi enam aspek, yaitu : keterbukaan, transparansi, konsensus dan tidak memihak, efektif dan relevan, koheren dengan standar internasional dan berdimensi pembangunan. Di antara berbagai SNI yang telah ditetapkan oleh BSN, belum ada satu pun yang menetapkan standar untuk produk biometrik. Padahal produk teknologi biometrik telah banyak beredar di masyarakat. Mesin presensi memakai sidik jari yang banyak dipakai di perkantoran dan sekolah adalah contoh yang paling mudah ditemukan. Selain itu, peralatan kepolisian seperti Mambis (Mobile Automated Multibiometrics Identification) yang dipakai untuk identifikasi korban kecelakaan atau kriminal, Perangkat Pembaca KTP elektronik yang dipakai di perbankan, bahkan smartphone terkini memanfaatkan biometrik sidik jari dan iris untuk fitur smart unlock. Oleh karena itu, pengembangan standar produk teknologi biometrik merupakan hal yang penting untuk menjamin kepercayaan pengguna teknologi otentikasi. Terutama saat teknologi tersebut diimplementasikan pada populasi berskala besar, misalnya pemanfaatan biometrik dalam proses penunggalan penduduk program KTP elektronik. Standar dalam biometrik dibutuhkan untuk menjamin interoperabilitas, agar terhindar dari vendor lock-in. Interoperabilitas ini memungkinkan integrasi modular dari berbagai produk, tanpa harus mengorbankan lingkup arsitektur. Proses upgrade tiap komponen dapat berlangsung dengan mudah, sehingga terhindar dari kondisi obsolete (usang).

Pusat Teknologi Informasi \& Komunikasi BPPT dilibatkan dalam penyusunan Rancangan Standar Nasional Indonesia untuk produk teknologi biometrik sebagai anggota Komite Teknis 35-01 Teknologi Informasi dan Konseptor Standar Biometrik. Hingga kini, beberapa standar yang telah dihasilkan :

1. SNI ISO/IEC 2382-37: Teknologi Informasi - Kosakata Bagian 37: Biometrik

2. RSNI ISO/IEC 19794-2 : Teknologi Informasi - Format Pertukaran Data Biometrik Bagian 2: Data Minutiae Jari

3. RSNI ISO/IEC 19794-4 : Teknologi Informasi - Format Pertukaran Data Biometrik Bagian 4: Data Citra Jari.

Sedangkan tahun 2020 ditargetkan menyelesaikan standar data citra wajah yang sangat diperlukan industri biometrik pengenalan wajah. 


\section{H.Pusat Unggulan Iptek (PUI) Biometrik dan Layanan Teknologi}

BPPT telah memiliki Pusat Unggulan Iptek (PUI) di bidang Biometrik, yang ditetapkan oleh Kementrian Riset dan Teknologi pada tahun 2019. Pembinaan PUI dilakukan oleh Kementrian Riset dan Teknologi untuk mampu menghasilkan inovasi teknologi berbasis demand driven dalam rangka mendukung peningkatan daya saing pengguna teknologi, seperti industri, pemerintah, dan masyarakat. Tiga faktor yang dinilai dan dipantau oleh kemenristekdikti, yaitu capaian Sourcing Absorptive Capacity, Research \& Development Capacity serta Disseminating Capacity. Pusat Unggulan Iptek Biometrik ini memiliki berbagai aktivitas penelitian dan layanan teknologi. Beberapa hal yang dicapai antara lain membantu pelaksanaan e-pemilu di berbagai daerah yang otentikasinya memakai teknologi biometrik sidik jari, layanan teknis untuk industri pengembang KTP-el Reader dalam pengujian komponen biometrik pada Perangkat Pembaca, maupun membantu Dukcapil Kemendagri dalam proses Transfer-of-Knowledge teknologi biometrik.

\section{PENUTUP}

Makalah ini merangkum kegiatan litbangyasa dan layanan teknologi di bidang teknologi kecerdasan buatan yang dilakukan Badan Pengkajian dan Penerapan Teknologi (BPPT). Kegiatan litbangyasa yang dilakukan beragam, meliputi teknologi pemrosesan bahasa alami, diagnosis Malaria, dan identifikasi individu lewat ciri khas anatomi atau perilaku seseorang yang disebut biometrik. Dalam kegiatan litbangyasa tersebut, dilakukan kerjasama dengan mitra dalam dan luar negeri. Misalnya dengan UNL, PAN Localization, ASEAN-MT, U-STAR maupun yang lain. Produk komersial yang berhasil dihasilkan antara lain "Perisalah", bekerjasama dengan PT.INTI sebagai mitra. Upaya juga dilakukan untuk merintis standarisasi (SNI) untuk membantu produk biometrik. Misalnya format penyimpanan data sidik jari dalam chip KTP elektronik. Untuk membantu industri di bidang kecerdasan buatan, BPPT memberikan layanan teknologi misalnya pengujian perangkat pembaca KTP elektronik. Sejak tahun 2017, BPPT memiliki Pusat Unggulan Iptek Biometrik (ditetapkan tahun 2019) yang mengintegrasikan kegiatan litbangyasa dan layanan teknologi, untuk mendukung kecerdasan buatan, khususnya di bidang biometrik.

\section{REFERENSI}

[1] S, Funaki (1993): Multilingual Machine Translation (MMT) project. in Proceedings of the Machine Translation Summit IV, 73-78, Kobe, Japan, July 20-22, 1993

[2] H. Uchida and M. Zhu, "Interlingua for Multilingual Machine Translation", in Proceedings of the Machine Translation Summit IV, Kobe, Japan, July 20-22, 1993.

[3] H. Uchida, UNL: Universal Networking Language - An Electronic Language for Communication, Understanding, and Collaboration, UNU/IAS/UNL Center, Tokyo, Japan. 1996.

[4] A. Santosa et al., "Utilizing Indonesian Data Resources for Text-To-Speech Using End-To-End Method," in The 21st Conference of the Oriental COCOSDA, 2018. 
[5] M. Gunawan et al., "Uji Coba Korpus Data Wicara BPPT sebagai Data Latih Sistem Pengenalan Wicara Bahasa Indonesia," Jurnal Linguistik Komputasional, Vol 1, No 2, 2018

[6] N.D. Kania, T. Lukito, A.S. Nugroho, I.E. Rozi, M. Gunawan, V. Pragejsvara, D.Anggraini, "Blood Component Classification for Malaria Computer Aided Diagnosis from Thin Blood Smear Microphotographs", 5th International Symposium on Computational Science (ISCS), 15-16 May 2012

[7] T. Lukito, N.D. Kania, I.E. Rozi, A.S. Nugroho, M. Gunawan, V. Pragejsvara, D. Anggraini, "Semi-auto mated Computer-aided Diagnosis for Malaria Multi species Parasite Detection from Thin Blood Smear Microphotographs", 5th International Symposium on Computational Science (ISCS), 15-16 May 2012

[8] D. Anggraini, A.S. Nugroho, C. Pratama, I.E. Rozi, V. Pragesjvara and M. Gunawan, "Automated Status Identification of Microscopic Images Obtained from Malaria Thin Blood Smears using Bayes Decision: A study case in Plasmodium Falciparum", Proc. of International Conference on Advance Computer Science and Information System 2011, Jakarta, Indonesia, 17-18 December 2011

[9] D. Anggraini, A.S. Nugroho, C. Pratama, I.E.Rozi, A.A. Iskandar, R.N. Hartono, "Automatic Status Identification of Microscopic Images Obtained from Malaria Thin Blood Smears", Proc. of 3rd International Conference on Electrical Engineering and Informatics (ICEEI 2011), CDROM A3-2, Institut Teknologi Bandung, Bandung, Indonesia, July 17-19, 2011

[10] G. Hartanto, A.S. Nugroho, A. Djajadi, R. Kusumajaya, M.J. Riski, M. Gunawan, V. Pragesjvara, U. Salamah, I.E. Rozi, P.B.S. Asih, "Automated Parasite Identification Device for Malaria Thick Blood Smear Microphotographs," submitted to International Journal on Electrical Engineering and Informatics

[11] U. Salamah, A.S. Nugroho, I.E. Rozi, P.B.S. Asih, Morphological Feature Extraction from Low Quality of Thick blood smear Microphotograph, The 5th International Conference on Science in Information Technology, pp.44-48, Yogyakarta, Indonesia, 2019

[12] U. Salamah, R. Sarno, A.Z. Arifin, A.S. Nugroho, I.E. Rozi, P.B.S Asih, A Robust Segmentation for Malaria Parasite Detection of Thick Blood Smear Microscopic Images, International Journal on Advanced Science, Engineering, Information and Technology (IJASEIT), Vol.9, No.4, 2019

[13] U. Salamah, R. Sarno, A.Z. Arifin, Sarimuddin, A.S. Nugroho, I.E. Rozi, P.B.S Asih, Segmentation of Malaria Parasite Candidate from Thickblood Smear Microscopic Images using Watershed and Adaptive Thresholding, Journal of Telecommunication, Electronic and Computer Engineering (JTEC), Vol.10, No.2-4, 2018

[14] U. Salamah, R. Sarno, A.Z. Arifin, A.S. Nugroho, I.E. Rozi, P.B.S Asih, Enhancement of Low Quality Blood Smear Image using Contrast and Edge Corrections, accepted for publication in International Journal of Biomedical Engineering and Technology

[15] U. Salamah, R. Sarno, A.Z. Arifin, A.S. Nugroho, I.E. Rozi, P.B.S Asih, Incorporating Index of Fuzziness and Adaptive Thresholding for Image Segmentation, International Journal of Electrical and Computer Engineering (IJECE), Vol.8, No.4, August 2018

[16] B. Miller B, Everything you need to know about biometric identification. Personal Identification News 1998 Biometric Industry Directory, Warfel \& Miller, Inc., Washington DC

[17] J. Wayman, A definition of biometrics National Biometric Test Center Collected Works 1997-2000, San Jose State University

[18] Situs Iris Challenge Evaluation http://iris.nist.gov/ice/ice2006.html 
[19] P.J. Phillips, T. Scruggs, A.J. O’Toole, P.J. Flynn, K.W. Bowyer, C.L. Schott and M. Sharpe, "FRVT 2006 and ICE 2006 Large-scale Experimental Results ", IEEE Trans. PAMI, Vol.32, No.5, pp.831-846, 2010

[20] J. Daugman, "How Iris Recognition Works," in IEEE Transactions on Circuits and Systems for Video Technology, 14, 1, Jan. 2004

[21] C.Valentina, R.N. Hartono, T.V. Tjahja, A.S. Nugroho, "Iris Localization using Circular Hough Transform and Horizontal Projection Folding", Proc. of International Conference on Information Technology and Applied Mathematics 2012, pp.64-68, 6 September 2012

[22] S. Sentanoe, A.S. Nugroho, M. Galinium, R.N. Hartono, M.T. Uliniansyah, M. Layooari, Iris Localization using Gradient Magnitude and Fourier Descriptor, Proc. Of International Conference on Advanced Computer Science \& Information Systems, pp.177-181, October 18-19, 2014, Jakarta, Indonesia

[23] D. Sulaeman, A.S. Nugroho, M. Galinium, Iris Segmentation using Gradient Magnitude and Fourier Descriptor for Multimodal Biometrics Authentication System, Journal of ICT Research and Applications, Vol.10, No.3, pp.209-227, 2016

[24] Hammam Riza, Budiono, C. Hakim, Collaborative work on Indonesian wordnet through Asian wordnet (AWN), Proceedings of the 8th Workshop on Asian Language Resource, page 9-13, 2010

[25] Francis Bond, Lian Tze Lim, Enya Kong Tang and Hammam Riza, The combined Wordnet Bahasa, NUSA: Linguistic studies of languages in and around Indonesia 57: pp 83-100, 2014 